The Service Industries Journal

Vol. 28, No. 10, December 2008, 1339-1356

\title{
Innovation in services - how different from manufacturing?
}

\author{
Cesaltina Pacheco Pires ${ }^{\mathrm{a}, \mathrm{b} *}$, Soumodip Sarkar ${ }^{\mathrm{a}, \mathrm{b}}$ and Luísa Carvalho ${ }^{\mathrm{c}, \mathrm{d}}$ \\ ${ }^{a}$ CEFAGE-UE, Évora, Portugal; ${ }^{b}$ Departamento de Gestão, Universidade de Évora, Largo dos \\ Colegiais, $n$ 2, Évora, Portugal; ${ }^{c}$ CICE-ESCE-IPS, Setúbal, Portugal; ${ }^{d}$ Departamento de \\ Economia e Gestão, Instituto Politecnico de Setúbal, Setúbal, Portugal
}

\begin{abstract}
Using standardised firm data a comparative analysis of the determinants of product and process innovation in manufacturing and services is performed. Results show that in services there are significant differences in innovation behaviour, in terms of intramural and extramural $R \& D$. It is also found that size matters less in services than in manufacturing. Although youth has a positive effect in both cases, young service firms are more likely than young manufacturing of being pioneer innovators. The results reveal the importance of learning by doing in service process innovations, as young service firms are less likely to introduce process innovations.
\end{abstract}

Keywords: product innovation; process innovation; entrepreneurship; services

\section{Introduction}

The study of innovation in the service sector is relatively recent and clearly under-represented in the innovation literature. In fact, until the early 1990s, the service sector was largely neglected. For instance, the OECD Oslo Manual (1992) and the first European Union (EU) innovation survey, called the Community Innovation Survey (CIS), were only designed for manufacturing firms. Both the Oslo Manual and the CIS-1 were mainly concerned with technological innovation, which is believed to be the main engine of economic growth, and the service sector was traditionally regarded as being less intensive in technological innovation.

Most studies on innovation at the macro level have focused on differences in innovation capability as an explanation for differences in economic performance, welfare and the source of competitive advantage for firms. However, very few of these studies have explicitly accounted for the service sector. This relative neglect is striking given that the service sector plays a fundamental role in the creation of jobs and in GDP value added, with policy-makers accounting for their importance, as well as innovation being a key source of improved output performance of service industries (Van Ark, Broesma, \& Hertog, 2003, p. 6).

The dearth of studies in services is perhaps justified due to the many specificities of this sector, for instance its heterogeneity. The service sector is a composite of many sub-sectors

*Corresponding author. Email: cpires@uevora.pt

ISSN 0264-2069 print/1743-9507 online

(C) 2008 Taylor \& Francis

DOI: $10.1080 / 02642060802317812$

http://www.informaworld.com 